\title{
Correction to: ReCiPe2016: a harmonised life cycle impact assessment method at midpoint and endpoint level
}

\author{
Mark A. J. Huijbregts ${ }^{1,2} \cdot$ Zoran J. N. Steinmann $^{1}$ - Pieter M. F. Elshout ${ }^{1} \cdot$ Gea Stam $^{1,3}$ - Francesca Verones ${ }^{4}$. \\ Marisa Vieira ${ }^{1,5} \cdot$ Michiel Zijp $^{3} \cdot$ Anne Hollander $^{3} \cdot$ Rosalie van Zelm ${ }^{1}$
}

Published online: 2 July 2020

(C) The Author(s) 2020

\section{Correction to: Int J Life Cycle Assess (2017) 22:138-147 https://doi.org/10.1007/s11367-016-1246-y}

The article [ReCiPe2016: a harmonised life cycle impact assessment method at midpoint and endpoint level], written by [Mark A. J. Huijbregts· Zoran J. N. Steinmann · Pieter M. F. Elshout - Gea Stam· Francesca Verones · Marisa Vieira· Michiel Zijp · Anne Hollander · Rosalie van Zelm], was originally published Online First without Open Access. After publication in volume [22], issue [2], page [138-147] the author decided to opt for Open Choice and to make the article an Open Access publication. Therefore, the copyright of the article has been changed to (C) The Author(s) [2017] and the article is forthwith distributed under a Creative Commons Attribution 4.0 International License (https:// creativecommons.org/licenses/by/4.0), which permits use, sharing, adaptation, distribution and reproduction in any medium or format, as long as you give appropriate credit to

The online version of the original article can be found at https://doi.org/ 10.1007/s11367-016-01246-y

Mark A. J. Huijbregts

m.huijbregts@science.ru.nl

1 Department of Environmental Science, Institute for Water and

Wetland Research, Faculty of Science, Radboud University,

Nijmegen, The Netherlands

2 Dutch Environmental Assessment Agency (PBL), The Hague, The Netherlands

3 National Institute for Public Health and the Environment, Centre of Sustainability, Environment and Health (DMG), Bilthoven, The Netherlands

4 Industrial Ecology Programme, Department for Energy and Process Engineering, Norwegian University and Science (NTNU), Trondheim, Norway

5 PRé Consultants, Amersfoort, The Netherlands the original author(s) and the source, provide a link to the Creative Commons license, and indicate if changes were made.

The original article has been corrected.

Open Access This article is licensed under a Creative Commons Attribution 4.0 International License, which permits use, sharing, adaptation, distribution and reproduction in any medium or format, as long as you give appropriate credit to the original author(s) and the source, provide a link to the Creative Commons licence, and indicate if changes were made. The images or other third party material in this article are included in the article's Creative Commons licence, unless indicated otherwise in a credit line to the material. If material is not included in the article's Creative Commons licence and your intended use is not permitted by statutory regulation or exceeds the permitted use, you will need to obtain permission directly from the copyright holder. To view a copy of this licence, visit http://creativecommons.org/licenses/by/4.0/.

Publisher's note Springer Nature remains neutral with regard to jurisdictional claims in published maps and institutional affiliations. 